\title{
Requirements of Facing Change Resistance in Damietta University from Its Faculty Members' Points of View
}

\author{
Aly S. Gohar, Mayada M. F. El-Basil, Mohammed H. Gomaa \\ Department of Foundation of Education, Faculty of Education, Damietta University, Damietta, Egypt \\ Email: gohar.1140@yahoo.com, MayadaelBasel@gmail.com, Moh-has74@yahoo.com
}

How to cite this paper: Gohar, A. S., El-Basil, M. M. F., \& Gomaa, M. H. (2018). Requirements of Facing Change Resistance in Damietta University from Its Faculty Members' Points of View. Creative Education, 9, 2773-2790.

https://doi.org/10.4236/ce.2018.916208

Received: September 25, 2018

Accepted: December 15, 2018

Published: December 18, 2018

Copyright ( $\odot 2018$ by authors and Scientific Research Publishing Inc. This work is licensed under the Creative Commons Attribution International License (CC BY 4.0).

http://creativecommons.org/licenses/by/4.0/

\begin{abstract}
This research aimed to address Change Resistance phenomenon in Damietta University from its faculty members' points of views and the requirements of facing this phenomenon. The research also examined the concept of Change Resistance and change resistance manifestations, change resistance types in Damietta University and the proposed vision to deal with this resistance. Then the research concluded to effective mechanisms through which trend towards change acceptance in Damietta University is promoted. The research analyzed change resistance reality in Damietta University by a specialized field study. The field study revealed that change resistance is the most prominent feature of the faculty members due to several reasons which are considered the major hindrance of change acceptance. The current study offered a proposed vision of change resistance requirements to promote the trend towards development and change among the faculty members of Damietta University in the light of the field study results.
\end{abstract}

\section{Keywords}

Requirements, Change Resistance, Damietta University, The Faculty Members

\section{Introduction}

No one denies that Egypt seeks university excellence. This excellence that driven by the conviction that "Education" is the key of progress and advancement, and that university is the main guarantor of this excellence. Thus, Believing in change and reform is the first conviction, now, to keep up with local and global successive challenges.

The real start of change breaks out of believing in it by coordination of differ- 
ent university categories and various functions. This desired change is the hope towards building modern university system. Therefore, nations work on building their promising future through tough will of change for better. This desired change is not just fantasy, but visions and realistic frameworks being built according to standardized methodology and shifted from the strategic planning framework into realistic applied framework in order to make these visions a new reality achieving mutations at all levels of the entire state sectors (Mushier, 2013).

University Education is not out of the will of change; according to several global rankings, it is very far from keeping up with globalization and its ratings do not reflect, anyway, Egypt's leading position throughout history. Therefore, it is a must to study ways of developing the Egyptian university education to keep up with the global rankings. So, interest in university education is the focus of this research, which deals with reasons of change resistance in Damietta University, concluding to implementation of this practical reality and identifying reasons \& forms of change resistance and assessing this rejection within Damietta University as an example of Egyptian Universities and surveying its faculty members' opinions to examine the aspects of this rejection and to identify methods to overcome it.

The current research highlights Change Resistance concept and the philosophical thought that rejects change and its reasons, and the university reality in the light of the educational climate that rejects change \& reform visions and expressively resists them.

The research also presents a case study of Damietta University to define requirements of facing change resistance, ending to establishing a new mechanism that enables the university to eliminate reasons of change rejection and integrate all faculty members and staff of the university in new system framework in which all members from different levels and functions harmonize to formulate new Egyptian university reality that believes in Excellence, Modernity and Keeping up the global visions of improving university management $\&$ its educational outputs improvement.

\section{The Theoretical Framework}

\section{First: Change Resistance "Concept and Philosophy"}

(Nasser, 2014; Federston, 2000) states that, all global educational systems believe that education, specifically university education, has a distinctive role; that is due to its effectiveness in supporting issues concerning Democracy, Good Management, Human Rights, Assuring Market \& Capital Privacy and Advocating Globally Redistribution of Social Justice. (Farag, 2000), (Al-Qattamin, 2002), (Maher. 2007), (Al-Da'dy, 2011), suggest that university management is in need for quantum leap towards innovation, excellence and development in order to fulfill demands of their faculty members to understand the new visions of Quality, requirements of self and institutional development that $21^{\text {st }}$ century challenges impose on the entire Arab universities. 
From this point, society considers education as the development locomotive that can lead the society towards better future. Thus, hopes are all set on education, especially; all states of the developed world have made great leaps, economically, socially, culturally and in comprehensive development through university educational reform and adopting more resilient policies for the advancement of university education frameworks. According to (Aceedo, 2014; Gohar \& Al-Basil, 2016) university education in Egypt comes in to lower rank according to global university rankings and according to societal perspectives which do not believe in the ability of Egyptian university education to bring about the required renaissance. Accordingly, it was the public great disappointment with this type of education.

But if the change resistance springs from the inside of the universities, it is a matter of interest. Most of Egyptian universities staff of different levels and functions; faculty members, their assistants or administrators of these universities do not accept so-called "Change". Moreover, they adopt so-called "Change Resistance” that rejects effective managerial innovation (Gohar \& Al-Basil, 2018).

According to this Research, Change Resistance is: "adopting policies that reject every thought for developing the universities at the academic, technical or administrative levels, due to considerations and convictions embraced by those of rejection thought"

This rejection inside the university reflects the societal dissatisfaction with the educational outputs of the Egyptian universities. From the society point of view, these universities were expected to achieve the following objectives: according to (Nasser, 2014; Gohar, 2012)

- The ability to critical and innovative thinking.

- Acceptance the responsibility of contributing to creating the desired change towards the future.

- The ability to logical analyzing and deriving for realizing knowledge and making the rational decision.

- Working within teamwork.

- Preparing the Egyptian graduates for labour market internationalization through understanding other civilizations.

- Providing graduates with effective communication skills.

- Being flexible and committed.

- Considering the long-life learning and being ready for it.

- Talent multiplicity in general skills that permeate into different systems and know-how of knowledge that constitutes the foundation of different professional skills as in modern technologies.

When the popular aspiration of university education and we see that rejection forces in these universities dominates the scene, so it does worth studying and careful researching to refute these reasons and investigate their justifications, particularly, we suffer from poor university outputs in all specializations every year. 
That is at the level of the simple public visions and their aspirations of education, but there are other unfulfilled aspirations of experts that increased the pace of educational rejection and resistance. These aspirations demonstrate in (Ammar, 2014):

- Acknowledging gratis education and equal opportunities for all.

- Acknowledging creating powerful entities of faculty members in Egyptian universities, strongly exercise the policy of putting pressures for making the rational educational decision; by forming alliances with societal pressure forces and civil society organizations.

- Acknowledging university education equity and developing its curricula, administrative and academic components to cope up with successive global evolutions and to emphasize those principles as a sound foundation for promoting trend towards development and reform.

- Heading for labour market through improving the university product; for promoting global competitiveness and meeting society needs for graduates with labour market skills that is the main function of university.

- Actual taking to "Quality" of university education and bridging the gabs between public university education and private university education within the same country.

(Abdul-Hameed, et al. 2004; Filliah, 2007; Al-Hout, 2004; Gomaa, 2015) indicate that, talking about those unfulfilled goals so far under faults the Egyptian education, particularly university education, suffers from, it demonstrates the societal dissatisfaction with education either from outside the field and the dissatisfaction with educational practices by the practitioners. Analyzing education practitioners' dissatisfaction is the essence in the present research; as the main question remains "Why do university education associates reject the will of change?" Why do they resist this change so fiercely that they turn on rejection forces that support constant failure of University education in Egypt to keep up with globalization?

The answer for this raising question could not be, anyway, the corruption of university education associates as much as being related to wrong administrative, academic and professional practices that have promoted the permanent sense of rejection of development vision inside those associates.

\section{Second: Reasons of Change Rejection in University Education}

(Al-Hout, 2005) reported that the main reasons are:

- Failure of university education to improve living standards and enhance the quality of life in our rapidly changeable world.

- Failure of university education to meet requirements of economic development through improving the quality of human resources and meeting the socio-economic development requirements.

- Failure of university education to meet the poor demands and to be reachable for them all.

- Failure of university education to support foundations of national security. 
- Failure of university education to be the focus of the comprehensive government expenditure.

- Failure of university education to be integrated into the Egyptian societal context to which it belongs.

- Failure of university education to achieve constant performance development and to keep up with successive global challenges.

These missing goals of the university scene may perfectly summarize the reasons for change rejection and resistance; through an educational system do not achieve the desired goals. Such education is restricted to rejection forces that hinder its progress. These forces believe that change will not occur and are convinced that they have the strong power to bring it down as long as it does not meet their goals.

\section{Third: Indicators of Change Acceptance:}

The change rejection \& resistance from higher education associates is due to failure to achieve the goals that (Tilac, 2008; Flouridi, 2017) identified as indicators of change acceptance:

1) Higher Education helps build the economy in tremendous speed; as it provides human capacities with professional, technical and administrative skills.

2) Higher Education helps create and support innovation and excellence. It is fixed in minds that universities are the caretakers of thought, innovation and development. They are also turning gradually into knowledge stores.

3) Higher Education builds individuals' character and morals, implants the moral values, ethics and respected norms, forms attitudes and integrates them into the society.

4) Higher Education helps charge liveliness and deepens democracy through making better citizen who effectively participates in civil action.

5) Higher Education contributes to developing and improving education in general and at all levels, and allows individuals to acquire unique mental abilities.

Therefore, there is a huge gap between the expected goals and real suffers and faults at the university level which (Filliah, 2007) summarized in the following:

- Poor university management; that is the main reason of low level of management.

- Poor, old admission policies in the Egyptian Universities that need to be amended.

- Spread of Bureaucracy within university education institutions in Egypt that negatively affects them resulting corruption.

- The huge gap between the university education and labour market requirements; as current university education is unmatched with required labour market skills.

- Untrained cadres that control sectors of diverse university functions that badly affects significance of education.

(Gohar, 2011) indicates that they are:

- The huge gap between the reality of university education in Egypt and global 
levels of university education.

- Reducing governmental shares of education finance. Thus, widely spread of privatization in education.

- Spread of private university without proper coordination with public university. Thus, the gap between them has been increased, and then the private universities have attracted the efficiencies while public universities are no longer able to compete.

- The tremendous increase of the students numbers without proper capacity plans.

- The disproportion between faculty members and students, that creates bad reality at the academic level in the Egyptian Universities; that implies the importance of thinking about new plans for capacity.

Fourth: Reasons for change rejection in Damietta University

The major indicators, according to the research's investigation of reality:

1) The variance between theoretical and practical universities regarding numbers of students and admission terms.

2) Poor administrative climate including university.

3) Poor educational climate that suffers from shortage of resources, shortage at expenditure level and shortage of required educational efficiencies.

4) Lack of societal participation as an essential component of societal support to education in Damietta University.

5) Conflicting and overlapping of administrative decisions and functions in Damietta University.

6) Centralization control over higher education management by The Higher Council of Universities in Egypt.

7) Prevailing of bad human relationships over the university.

8) Feeling of discontent with "Quality" modern trends; due to the huge gap between reality and theory.

9) Discontent with salaries of university associates in Egypt, compared with other jobs such as judges, policemen...etc.

Therefore, Change Resistance at the university education level is not surprising. The world has been establishing universities meet the global standards; as they are considered substantial components in its developmental programs for renaissance, reform and convoy Globalization with all it superiorities (Gohar \& Al-Basil, 2016; Al-Khouli, 2013).

(Aceedo, 2012) suggests convoy education for peace and understanding among diverse cultures; that believes in the major goal of university education is to be means of containing international ideals \& principles, learning international languages, acquiring global vision for comprehensive desired reform.

Hereby, there is a huge gap between aspirations and reality of university education. Thus the societal discontent with university education in Damietta is justified as well as internal change resistance of the faculty members. Therefore, the following section of this research is surveying the study sample' (the faculty members of Damietta University) points of view on the reasons of change resis- 
tance from their perspectives; for analyzing aspects of resistance and building a proposed conceptual enables us to realize satisfaction with change within the university institution in Egypt.

\section{Field Study}

This section covers the applied part of the research, through which the researchers could identify the main forms of change resistance, the major reasons for change resistance and the main methods of overcoming change resistance in Damietta University.

Guided by previously mentioned, the field study is divided into two pivots: first, the field study procedures. Second, the field study results analysis and requirements of facing change resistance in the light of the field study results. Both pivots are discussed in details as follows:

\subsection{Objectives of the Field Study}

This study directly examines the requirements of facing change resistance in Damietta University from its faculty members' points of view, through a number of procedures; identifying the main forms of change resistance in Damietta University, identifying the major reasons for change resistance in Damietta University and finding the main methods of overcoming change resistance in Damietta University.

\subsection{Methodology}

The researchers used the Survey Analytic Descriptive Approach; that is a survey field study that examines the sample of Damietta University faculty members' points of view.

\subsection{The Population of the Field Study}

The Population of study is selected from the faculty members of Damietta University.

\subsection{Selecting the Study Sample Technique}

The success of the field study and achieving its goals depend, to great extent, on well-chosen sample. The good representative sample of the original population helps get accurate evident results.

It is often difficult for the researcher, upon examining a phenomenon in a society, to examine this phenomenon using the entire society population. It may be difficult or even impossible to examine or observe all individuals under controlled conditions. Thus, researcher often selects a sample of the original society, trying to get a sample that carries all attributes and characteristics of the original society. He does it according to available time, effort, potentialities. Then he starts to examine it and generalizes its characteristics on the whole group. The study sample categories were selected from different university departments in 
Damietta University.

\subsection{The Study Samples Description}

The study sample consisted of (20) faculty members in Damietta University*; described in Table 1.

\subsection{Instruments of the Field Study}

According to the objectives that the field study seeks to achieve, the researchers used "Questionnaire", including a number of pivots; it is divided in to the three following pivots: (Table 2).

First: The main forms of change resistance.

Second: The major reasons for change resistance in the university.

Third: The main methods of overcoming change resistance in the university.

Table 1. Degree, number, gender and faculties of the study sample (faculty members of Damietta University.

\begin{tabular}{|c|c|c|c|c|}
\hline \multirow{2}{*}{ Degree } & \multirow{2}{*}{ No. } & \multicolumn{2}{|c|}{ Gender } & \multirow{2}{*}{ Faculty they are associated to } \\
\hline & & Male & Female & \\
\hline \multirow{3}{*}{ Professor } & \multirow{3}{*}{5} & \multirow{3}{*}{2} & \multirow{3}{*}{3} & 1) Faculty of engineering 5 \\
\hline & & & & 2) Faculty of education \\
\hline & & & & 3) Faculty of agriculture \\
\hline \multirow{5}{*}{ Professor-Assistant } & \multirow{5}{*}{7} & \multirow{5}{*}{6} & \multirow{5}{*}{1} & 1) Faculty of engineering \\
\hline & & & & 2) Faculty of education \\
\hline & & & & 3) Faculty of science \\
\hline & & & & 4) Faculty of arts \\
\hline & & & & 5) Faculty of commerce. \\
\hline \multirow{8}{*}{ Lecturer } & \multirow{8}{*}{8} & \multirow{8}{*}{4} & \multirow{8}{*}{4} & 1) Faculty of agriculture, \\
\hline & & & & 2) Faculty of education \\
\hline & & & & 3) Faculty of science \\
\hline & & & & 4) Faculty of specific education \\
\hline & & & & 5) Faculty of applied arts \\
\hline & & & & 6) Faculty of monuments \\
\hline & & & & 7) Faculty of Law \\
\hline & & & & 8) Faculty of physical education. \\
\hline
\end{tabular}

Table 2. The study pivots distribution \& number of items in each pivot.

\begin{tabular}{|c|c|c|}
\hline No. & Pivot & Number of Items \\
\hline 1 & 10 & 10 \\
\hline 2 & 15 & 15 \\
\hline 3 & 15 & 15 \\
\hline \multicolumn{2}{|c|}{ Total } & 40 \\
\hline
\end{tabular}




\subsection{Procedures of the Questionnaire Forming}

Analyzing data \& information which the researchers elicited from reviewing educational literatures and analyzing relevant previous studies.

Formulating the questionnaire items to be objective, clear, and simple in style to give the target meaning, so that the questionnaire can achieve its desired goals.

Setting the questionnaire items in logical sequence to help the sample individuals and attract their attention for proper answers.

Drafting the questionnaire.

Questionnaire Validity

Questionnaire validity means: the items assess what they have been set for. The researchers tested the questionnaire validity by two techniques:

\section{First: Internal Validity:}

It means how consistent each item is with the pivot it belongs to. The researchers calculated the questionnaire internal validity by calculating correlation coefficients between the score of each item and the total score of the pivot to which it belongs.

\section{Second: Intrinsic Validity:}

The intrinsic validity is assessed by calculating the Sqrt of the questionnaire reliability coefficient, as following:

Intrinsic validity coefficient $=(\text { questionnaire reliability coefficient })^{1 / 2}$

Questionnaire Reliability:

It means the questionnaire gives the same result, if it has been redistributed more than once under the same circumstances and conditions. In other words, Questionnaire Reliability means stability of the questionnaire results and nonchange of them significantly, in case of redistribution of the questionnaire over the sample several times over time.

\section{First: Results of Questionnaire items Internal Validity}

The following Table 3 shows correlation coefficients(r) between score of each item and the total score of the first pivot to which it belongs. The pivot includes (10) items that demonstrate manifestations of change resistance among faculty members of Damietta University.

Table 3 shows correlation coefficients between score of each item and the total score of the first pivot to which it belongs, that varied between $(0.579-0.903)$. All of them are statistically significant at significance level (0.001). So, the questionnaire items are considered valid.

Table 4 contains correlation coefficients of each item score and the total score of the second pivot to which it belongs, the pivot consists of (15) items demonstrate the greatest hindrances that prevent conviction of change. The faculty members of Damietta University think that hindrances really affect their feeling of loyalty and belongingness to the university which is supposed to meet their right ambitions and aspirations. Those hindrances need urgent intervention. 
Table 3. Correlation coefficients ( $r$ ) between score of each item and the total score of the first pivot to which it belongs.

\begin{tabular}{|c|c|c|c|c|}
\hline No. & Item & $\mathrm{r}$ & $\begin{array}{l}\text { Sign. } \\
\text { level }\end{array}$ & $\begin{array}{l}\text { Statistic } \\
\text { Sign. }\end{array}$ \\
\hline 1 & Indifference in doing their assigned jobs. & 0.795 & 0.001 & Significant \\
\hline 2 & Being late to university and lack of professional commitment. & 0.809 & 0.001 & Significant \\
\hline 3 & Deliberate morality sabotage of university's reform efforts. & 0.831 & 0.001 & Significant \\
\hline 4 & Frequent sick-leaves, which is in fact evasion from work. & 0.803 & 0.001 & Significant \\
\hline 5 & Absence; as a declaration of discontent and rejection of work. & 0.579 & 0.001 & Significant \\
\hline 6 & Procrastination, temporization and postponing assigned tasks. & 0.813 & 0.001 & Significant \\
\hline 7 & $\begin{array}{l}\text { Adhering to red-tape and regulations to obstruct workflow } \\
\text { and giving up flexibility. }\end{array}$ & 0.839 & 0.001 & Significant \\
\hline 8 & Slowly work , in purpose, as a result of feeling disappointed & 0.857 & 0.001 & Significant \\
\hline 9 & $\begin{array}{l}\text { Criticizing the institution, behind the back to } \\
\text { emphasize the bad climate }\end{array}$ & 0.869 & 0.001 & Significant \\
\hline 10 & $\begin{array}{l}\text { Awkward leaks about the bad conditions of } \\
\text { the university to media. }\end{array}$ & 0.903 & 0.001 & Significant \\
\hline
\end{tabular}

Table 4. Correlation coefficients of each item score and the total score of the second pivot to which it belongs.

\begin{tabular}{|c|c|c|c|c|}
\hline No. & Item & $\mathrm{r}$ & $\begin{array}{l}\text { Sign. } \\
\text { Level }\end{array}$ & $\begin{array}{c}\text { Statistic } \\
\text { Significance }\end{array}$ \\
\hline 1 & $\begin{array}{l}\text { Low payments in comparison to employees of } \\
\text { other institutions of the state }\end{array}$ & 0.791 & 0.001 & Significant \\
\hline 2 & $\begin{array}{l}\text { Weakness of available skills and lack of scientific } \\
\text { qualification system. }\end{array}$ & 0.868 & 0.001 & Significant \\
\hline 3 & $\begin{array}{l}\text { Feeling of inferior status in a society doesn't } \\
\text { appreciate university education. }\end{array}$ & 0.914 & 0.001 & Significant \\
\hline 4 & $\begin{array}{l}\text { Feeling of low respect in comparison with inferior } \\
\text { social categories. }\end{array}$ & 0.880 & 0.001 & Significant \\
\hline 5 & Unaccepted leaves and vacations, due to boring red-tape. & 0.888 & 0.001 & Significant \\
\hline 6 & Too little pension payments that hardly meet the basic needs & 0.844 & 0.001 & Significant \\
\hline 7 & $\begin{array}{l}\text { Lack of training and useless, superficial existing } \\
\text { training programs. }\end{array}$ & 0.861 & 0.001 & Significant \\
\hline 8 & Weak sense of job secured results lack of belongingness. & 0.835 & 0.001 & Significant \\
\hline 9 & Lack of authority due to centralization management style & 0.806 & 0.001 & Significant \\
\hline 10 & Low rate of self-satisfaction with job due to indifference. & 0.847 & 0.001 & Significant \\
\hline 11 & $\begin{array}{l}\text { Very few opportunities of initiation and innovation due to } \\
\text { lack of opportunities of innovation development. }\end{array}$ & 0.536 & 0.001 & Significant \\
\hline 12 & Low level of social integration and communication & 0.888 & 0.001 & Significant \\
\hline 13 & $\begin{array}{l}\text { Depressing Management Leaders due to their } \\
\text { lack of preparation and qualification. }\end{array}$ & 0.528 & 0.001 & Significant \\
\hline 14 & $\begin{array}{l}\text { University climate is not encouraging to self-realization } \\
\text { where there is no room for excellence. }\end{array}$ & 0.650 & 0.001 & Significant \\
\hline 15 & Too much bureaucracy in educational decision-making. & 0.566 & 0.001 & Significant \\
\hline
\end{tabular}


Table 4 shows correlation coefficients between the score of each item and the total score of the second pivot to which it belongs, that varied between $(0.528$ 0.914). All of them are statistically significant at the significance level (0.001). Thus, the questionnaire items are valid for what they are assessing.

The following Table 5 shows the correlation coefficients between score of each item and the total score of the third pivot to which it belongs. The 5th pivots includes (15) items reflect the main urgent effective actions to be taken for promoting culture of change acceptance among faculty members of Damietta University in accordance with contemporary trends based on surmounting hindrances and promoting openness to desired development and reform.

Table 5 shows correlation coefficients between the score of each item and the total score of the third pivot to which it belongs, that varied between $(0.711$ 0.953). All of them are statistically significant at the significance level (0.001). Thus, the questionnaire items are considered valid for what they are assessing.

Table 5. Correlation coefficients between score of each item and the total score of the third pivot to which it belongs.

\begin{tabular}{|c|c|c|c|c|}
\hline No. & Item & $\mathrm{r}$ & $\begin{array}{l}\text { Sign. } \\
\text { level }\end{array}$ & $\begin{array}{l}\text { Statistic } \\
\text { Sign. }\end{array}$ \\
\hline 1 & $\begin{array}{l}\text { More professional advancement and promoting opportunities } \\
\text { of development and progress. }\end{array}$ & 0.814 & 0.001 & Significant \\
\hline 2 & More speed response to staff demands and emphasizing them & 0.942 & 0.001 & Significant \\
\hline 3 & Reducing wasted university costs and re-evaluation of reality. & 0.940 & 0.001 & Significant \\
\hline 4 & $\begin{array}{l}\text { Support non-centralization of decision-making and provide the } \\
\text { power to the non-central management. }\end{array}$ & 0.838 & 0.001 & Significant \\
\hline 5 & Reducing work pressures rates and give opportunity for this. & 0.940 & 0.001 & Significant \\
\hline 6 & $\begin{array}{l}\text { Raising salaries according to fair administrative regulations } \\
\text { and procedures }\end{array}$ & 0.799 & 0.001 & Significant \\
\hline 7 & $\begin{array}{l}\text { Radical reforms in university administrative structures } \\
\text { within effective planning framework. }\end{array}$ & 0.816 & 0.001 & Significant \\
\hline 8 & $\begin{array}{l}\text { Legitimating the process of selecting university leaders } \\
\text { according to established visions and criteria. }\end{array}$ & 0.832 & 0.001 & Significant \\
\hline 9 & Eliminating Bureaucracy and promoting non-centralization. & 0.785 & 0.001 & Significant \\
\hline 10 & $\begin{array}{l}\text { Empowering the young leaders and giving them } \\
\text { real perceived opportunity. }\end{array}$ & 0.754 & 0.001 & Significant \\
\hline 11 & $\begin{array}{l}\text { Containment of internal conflicts and spread } \\
\text { sprit of dialogue and tolerance. }\end{array}$ & 0.711 & 0.001 & Significant \\
\hline 12 & $\begin{array}{l}\text { Managing crises efficiently according to validated } \\
\text { approved plan. }\end{array}$ & 0.725 & 0.001 & Significant \\
\hline 13 & $\begin{array}{l}\text { Create direct channels for communication with leaders and } \\
\text { promoting societal dialogue. }\end{array}$ & 0.716 & 0.001 & Significant \\
\hline 14 & $\begin{array}{l}\text { Enabling university institutions of self-evaluation fairly and } \\
\text { objectively. }\end{array}$ & 0.875 & 0.001 & Significant \\
\hline 15 & $\begin{array}{l}\text { Responding to the societal pressure for the good of the } \\
\text { country and the university within mutual respect framework. }\end{array}$ & 0.886 & 0.001 & Significant \\
\hline
\end{tabular}




\section{Second: Structure Validity Results}

Table 6 shows correlation coefficients between the total score of each pivot and the total score of the whole questionnaire that varied between $(0.626$ 0.965). So the questionnaire pivots are valid for what they are assessing.

\section{Third: Intrinsic Validity Results:}

Intrinsic Validity Results shown in reliability Table 6 are high, that means; there is a strong connection between intrinsic validity and reliability.

Fourth: Result of the Questionnaire \& Questionnaire pivots reliability:

The researchers tested the questionnaire reliability by Cronbach's Alpha Coefficient. The results were as shown in Table 7.

Table 7 shows reliability coefficient of the Questionnaire pivots that varied between $(0.990-0.968)$, and of the whole questionnaire that was (0.993). The values of intrinsic validity of pivots varied between $(0.995-0.984)$, and (0.993) of the whole questionnaire.

\section{Statistical Processing}

The researcher used Statistical Processing for Social Sciences (SPSS) technique, version 22 , to calculate the following:

1) Frequencies, hundred percentages and relative weighs.

2) Parson's correlation coefficient of validity.

3) Cronbach's Alpha Coefficient of reliability.

\section{Analysis of the Field Study Results}

In this chapter the opinions of the study sample (of Damietta University faculty members) are being analyzed.

Table 6. Correlation coefficients between the total score of each pivot and the total score of the whole questionnaire.

\begin{tabular}{|c|c|c|c|}
\hline Questionnaire Pivots & $\mathrm{r}$ & $\begin{array}{l}\text { Sign. } \\
\text { level }\end{array}$ & $\begin{array}{l}\text { Statistic } \\
\text { Sign. }\end{array}$ \\
\hline First pivot: The main forms of change resistance & 0.965 & 0.001 & Significant \\
\hline Second pivot: The major reasons for change resistance & 0.626 & 0.001 & Significant \\
\hline $\begin{array}{l}\text { Third pivot: The main methods of overcoming } \\
\text { change resistance in the university. }\end{array}$ & 0.922 & 0.001 & Significant \\
\hline
\end{tabular}

Table 7. Reliability coefficient of the Questionnaire \& Questionnaire pivots.

\begin{tabular}{lcc}
\hline \multicolumn{1}{c}{ Questionnaire Pivots } & $\begin{array}{c}\text { Cronbach's } \\
\text { Alpha Coefficient }\end{array}$ & $\begin{array}{c}\text { Intrinsic } \\
\text { Validity }\end{array}$ \\
\hline First pivot: The main forms of change resistance & 0.990 & 0.995 \\
$\begin{array}{l}\text { Second pivot: The major reasons for change resistance } \\
\text { Third pivot: The main methods of }\end{array}$ & 0.953 & 0.976 \\
overcoming change resistance in the university & 0.968 & 0.984 \\
The whole Questionnaire & 0.987 & 0.993 \\
\hline
\end{tabular}


The following Table 8 has (10) items have been statistically analyze.

The most effective components on change resistance have been put in serial order from 1:5 which highlight the sample's points of view in respective of the items.

The above table shows the results of the participants' (Damietta University faculty members) responses on the items of the first pivot; identifying the main forms of change resistance. According to the faculty members' points of view, the main (5) forms of change resistance are:

1) Adhering to red-tape and regulations to obstruct workflow and giving up flexibility.

2) Deliberate morality sabotage of university's reform efforts.

3) Indifference in doing their assigned jobs.

4) Criticizing the institution, behind the back to emphasize the bad climate.

5) Frequent sick-leaves, which is in fact evasion from work.

They all are phenomena do assure the prevailing climate within the institution. This emphasizes the importance of realizing this climate and analyzing its reasons in order to find new effective mechanisms to face it.

Table 9 shows the major reasons of change resistance in Damietta University. These reasons are the prominent hindrances the university has to consider; as their severity can lead to tremendous defect that ruins the university stability and education quality.

Table 9 shows the results of the participants' (Damietta University faculty members) responses on items of the second pivots; the main reasons for change resistance in the university. According to the faculty members' points of view, the main (5) reasons for change resistance are:

Table 8. Results of the participants responses on the first pivot items: The main forms of change resistance.

\begin{tabular}{|c|c|c|c|c|}
\hline \multirow{2}{*}{ No. } & \multirow{2}{*}{ Item } & \multicolumn{3}{|c|}{ Response } \\
\hline & & Freq. & $\%$ & Rating \\
\hline 1 & Indifference in doing their assigned jobs. & 12 & $60 \%$ & 3 \\
\hline 2 & Being late to university and lack of professional commitment. & 4 & $20 \%$ & \\
\hline 3 & Deliberate morality sabotage of university's reform efforts. & 13 & $65 \%$ & 2 \\
\hline 4 & Frequent sick-leaves, which is in fact evasion from work. & 7 & $35 \%$ & 5 \\
\hline 5 & Absence, as a declaration of discontent and rejection of work. & 3 & $15 \%$ & \\
\hline 6 & Procrastination, temporization and postponing assigned tasks. & 2 & $0.1 \%$ & \\
\hline 7 & $\begin{array}{l}\text { Adhering to red-tape and regulations to } \\
\text { obstruct workflow and giving up flexibility. }\end{array}$ & 17 & $85 \%$ & 1 \\
\hline 8 & Slowly work , in purpose, as a result of feeling disappointed & 3 & $15 \%$ & \\
\hline 9 & $\begin{array}{l}\text { Criticizing the institution, behind the } \\
\text { back to emphasize the bad climate }\end{array}$ & 9 & $45 \%$ & 4 \\
\hline 10 & Awkward leaks about the bad conditions of the university to media. & 5 & $25 \%$ & \\
\hline
\end{tabular}


Table 9. Results of the participants responses on the second pivot items: The major reasons of change resistance in the university.

\begin{tabular}{|c|c|c|c|c|}
\hline \multirow{2}{*}{ No. } & \multirow{2}{*}{ Item } & \multicolumn{3}{|c|}{ Response } \\
\hline & & Freq. & $\%$ & rating \\
\hline 1 & $\begin{array}{l}\text { Low payments in comparison to employees of } \\
\text { other institutions of the state }\end{array}$ & 15 & $75 \%$ & 1 \\
\hline 2 & $\begin{array}{l}\text { Weakness of skills and lack of scientific } \\
\text { qualification system. }\end{array}$ & 10 & $50 \%$ & 3 \\
\hline 3 & $\begin{array}{l}\text { Feeling of inferior status in a society doesn't } \\
\text { appreciate university education. }\end{array}$ & 1 & $0.05 \%$ & \\
\hline 4 & $\begin{array}{l}\text { Feeling of low respect in comparison with } \\
\text { inferior social categories. }\end{array}$ & 2 & $0.1 \%$ & \\
\hline 5 & Unaccepted leaves and vacations, due to boring red-tape. & 1 & $0.05 \%$ & \\
\hline 6 & $\begin{array}{l}\text { Too little pension payments that hardly } \\
\text { meet the basic needs }\end{array}$ & 7 & $36.8 \%$ & $\begin{array}{c}2 \\
\text { (repeated) }\end{array}$ \\
\hline 7 & $\begin{array}{l}\text { Lack of training and useless, superficial existing } \\
\text { training programs. }\end{array}$ & 3 & $0.15 \%$ & \\
\hline 8 & Weak sense of job secured results lack of belongingness. & 2 & $0.1 \%$ & \\
\hline 9 & Lack of authority due to centralization style & 4 & $25 \%$ & \\
\hline 10 & Low rate of self-satisfaction with job due to indifference. & 9 & $45 \%$ & 4 \\
\hline 11 & $\begin{array}{l}\text { Very few opportunities of initiation and innovation } \\
\text { due to lack of opportunities of innovation development. }\end{array}$ & 7 & $35 \%$ & 5 \\
\hline 12 & Low level of social integration and communication & 2 & $0.1 \%$ & \\
\hline 13 & $\begin{array}{l}\text { Depressing Management Leaders due to lack of } \\
\text { preparation and qualification. }\end{array}$ & 5 & $20 \%$ & \\
\hline 14 & $\begin{array}{l}\text { University climate is not encouraging to self-realization } \\
\text { where there is no room for excellence. }\end{array}$ & 13 & $65 \%$ & 2 \\
\hline 15 & Too much bureaucracy in educational decision-making. & 3 & $0.15 \%$ & \\
\hline
\end{tabular}

1) Low payments in comparison to employees of other institutions of the state.

2) University climate is not encouraging to self-realization where there is no room for excellence.

3) Weakness of skills and lack of scientific qualification system.

4) Low rate of self-satisfaction with job due to indifference.

5) Very few opportunities of initiation and innovation due to lack of opportunities of innovation development.

Therefore, the university climate suffers from many hindrances; financial, moral and technical, that extremely decreases the acceptance of change. As a result, the resistance forces have become an effective reality advocate their negative trends.

Table 10 the most important recommendations that can effectively contribute to procedures of over-coming change resistance in Damietta University. These procedures within which roles of state, university and society member integrate 
Table 10. Results of the participants' responses on the third pivot items: The main methods of overcoming change resistance in the university.

\begin{tabular}{|c|c|c|c|c|}
\hline \multirow{2}{*}{ No. } & \multirow{2}{*}{ Item } & \multicolumn{3}{|c|}{ Response } \\
\hline & & Freq. & $\%$ & rating \\
\hline 1 & $\begin{array}{l}\text { More professional advancement and promoting opportunities } \\
\text { of development and progress. }\end{array}$ & 3 & $0.15 \%$ & \\
\hline 2 & More speed response to staff demands and emphasizing them & 6 & $30 \%$ & \\
\hline 3 & Reducing wasted university costs and re-evaluation of reality. & 11 & $55 \%$ & 3 \\
\hline 4 & $\begin{array}{l}\text { Support non-centralization of decision-making and provide } \\
\text { the power to the non-central management. }\end{array}$ & 7 & $35 \%$ & \\
\hline 5 & Reducing work pressures rates and give opportunity for this. & 2 & $0.1 \%$ & \\
\hline 6 & $\begin{array}{l}\text { Raising salaries according to fair administrative regulations } \\
\text { and procedures }\end{array}$ & 18 & $90 \%$ & 1 \\
\hline 7 & $\begin{array}{l}\text { Radical reforms in university administrative structures } \\
\text { within effective planning framework. }\end{array}$ & 4 & $25 \%$ & \\
\hline 8 & $\begin{array}{l}\text { Legitimating the process of selecting university leaders } \\
\text { according to established visions and criteria. }\end{array}$ & 3 & $0.15 \%$ & \\
\hline 9 & Eliminating Bureaucracy and promoting non-centralization. & 1 & $0.05 \%$ & \\
\hline 10 & $\begin{array}{l}\text { Empowering the young leaders and giving them real } \\
\text { perceived opportunity. }\end{array}$ & 16 & $80 \%$ & 2 \\
\hline 11 & $\begin{array}{l}\text { Containment of internal conflicts and spread sprit of dialogue } \\
\text { and tolerance. }\end{array}$ & 2 & $0.1 \%$ & \\
\hline 12 & Managing crises efficiently according to validated approved plan. & 8 & $40 \%$ & 5 \\
\hline 13 & $\begin{array}{l}\text { Create direct channels for communication with leaders and } \\
\text { promoting societal dialogue. }\end{array}$ & 2 & $0.1 \%$ & \\
\hline 14 & $\begin{array}{l}\text { Enabling university institutions of self-evaluation fairly } \\
\text { and objectively. }\end{array}$ & 10 & $50 \%$ & 4 \\
\hline 15 & $\begin{array}{l}\text { Responding to the societal pressure for the good of the country } \\
\text { and the university within mutual respect framework. }\end{array}$ & 2 & $0.1 \%$ & \\
\hline
\end{tabular}

in pursuant to embrace new culture that believes in development and change among faculty members of Damietta University.

The above table shows the analysis results of the sample responses that identified the major problems with reform priorities of university education. The main (5) problems from the faculty members of Damietta University, perspectives are:

1) Raising salaries according to fair administrative regulations and procedures.

2) Empowering the young leaders and giving them real perceived opportunity.

3) Reducing wasted university costs and re-evaluation of reality.

4) Enabling university institutions of self-evaluation fairly and objectively.

5) Managing crises efficiently according to validated approved plan.

In the light of all above mentioned, the research suggests that university reform visions are able to greatly get the satisfaction of the staff within and associates through a group of effective actions including: establishing new financial 
structure for salaries and bonuses, empowering the young of management initiatives, rationalizing expenditures, accepting criticism and managing crises efficiently. All of that would enable the university to effectively manage change.

The research proposes a number of suggestions that would contribute to facing Change Resistance in Damietta University from its faculty members' points of view.

\section{Requirements of Facing Change Resistance in Damietta University in the Light of the Field Study Results}

Based on the theoretical and applied frameworks, the research concluded to a number of requirements that could help face change resistance in Damietta University from its faculty member points of view. These requirements are:

1) Functional Requirements:

a) Promoting loyalty $\&$ belongingness among faculty members of the university.

b) Creating sound democratic atmosphere within the university.

c) Enabling the faculty members of fair, just opportunities of promotions.

d) Fixing the salary systems of faculty members in Egyptian universities according to comprehensive insurance system that insures decent life for them and their families.

e) Enabling faculty members of publishing their international research according to fully sponsorship by universities within research encouragement system.

2) Human Requirements:

a) Building bridges of friendship and familiarity among the faculty members.

b) Give the faculty members opportunities to freely express their opinions without restriction, within respect of rules and regulations.

c) Expanding umbrella of comprehensive health insurance for them and their family to be treated humanely.

d) Broadening the human communication bases during social occasions to create friendly atmosphere.

e) Supporting the human, civilized climate in the university institutions.

3) Research \& Technical Requirements:

a) Enabling the faculty members of technology and its means with the support of the university.

b) Enabling the faculty members of accessing international information sources according to quality trends.

c) Enabling the faculty members of get benefit of university libraries within the framework of constant development and get use of the age innovations.

d) Training the faculty members on using the modern technology media according to contemporary quality visions.

e) Enabling the faculty members to be devoted to their researches within a framework of consistent visions with their universities according to legal decision regarding this matter. 
4) Global Requirements:

a) Supporting mechanisms of communication with global universities for getting benefit of global universities visions; within the framework of regulated openness to cultures.

b) Enabling the faculty members to get benefit of scholarships and grants to foreign university according to transparent fair, impartial regulations.

c) Enabling the faculty members of travelling abroad within framework of human, social\& professional development according to flexible regulations that insure them financial and psychological stability, and guarantee the university benefit from its abroad scholars accordingly with regulated visions.

d) Supporting faculty members' trends of communicating with international cadres in scientific research areas according to regulations approved by the university.

e) Enabling the faculty member of scientific publishing in review with powerful effect coefficients, and openness to these periodicals to promote scientific research.

5) Financial Requirements:

a) Raising salaries and wages according to a comprehensive reform plan.

b) Secure a new system for bonuses of supervisions and scientific researching.

c) Enabling the faculty members of conducting researches on the university expense.

d) Giving the faculty members packages of exceptional incentives \& bonuses.

e) Sponsoring their social occasion as proper as being faculty members of prestigious university.

\section{Conclusion}

The current research examines types of change resistance in Damietta University from its faculty members' points of view. It also investigated the major reasons of this resistance and reasons for feeling the strength of this trend that reject change. In addition, the research analyzed, within the theoretical framework, change resistance concept and forms. Then the research presented a field analysis that examined the most prominent hindrance that stand against adopting change management as well as the main negative manifestations of this resistance. It proposed a number of recommendations that contribute to promoting the attitude of faculty members in Damietta University towards change acceptance and desired development.

\section{Conflicts of Interest}

The authors declare no conflicts of interest regarding the publication of this paper.

\section{References}

Abdul-Hameed, T. et al. (2004) Global Education \& Society Modernization-A Study in 
Philosophical and Social Foundations of Education (p. 178). Cairo: Dar Rahma for Publishing and Distribution.

Aceedo, C. (2012) International Education Classes, Corresponding to Global Challenges. Futures, 42, 338. (Emad Eddin Abdul-Raziq, Trans.).

Aceedo, C. (2014). Required Skills for Sustainable Development: Perspectives from Pacific Ocean Area in Asia and Beyond. Futures, 44, 217.

Al-Da'dy, D. (2011). The Relationship between Empowerment and Innovative Management from Perspectives of Managerial Leader in Om Al-Qura University. Unpublished MA Thesis, Faculty of Education, Om Al-Qura.

Al-Hout, M. S. (2004). Poverty and University Education Funding, University Education, a Study on Development Issue, to: 11th Annual Conference (Arab 3rd), Ain Shams University, University Education Developmen Centre, Part (1), 18th-19th December, 44.

Al-Qattamin, A. (2002). Strategic Planning in Educational Institution, Analytic Applied Study. Economic \& Administrative Sciences Review, 18.

Ammar, H. (2014) Future Education from Autocracy to Liberty, The Egyptian Public Board for Books, Cairo, 35-37.

Farag, M. S. (2000). Creativity and Innovation in Arab Management and 21st Century and Challenges. In Conference of Innovation and Creativity in Arab Management. Cairo: Arab Organization for Administrative.

Federston, M. (2000). Globalization Culture (p. 246). Cairo: The Higher Council for Culture (Abdul-Wahhab Aloub, trans.).

Filliah, F. A. (2007). Education in Recovery Room (p. 74). Dar Al-Wafaa for Press \& Publishing, Alex.

Flouridi, L. N. (2017). 4th Revolution, How Do Informational Sphere Reconstruct the Human Reality. In The National Council for Culture, Arts and Literature, Kuwait (No. 452, p. 11). (Lu'ai Abdul-Majeed El-Sayed, Alaam Al-Maarifa, Trans.).

Gohar, A. S. (2012). Public \& Private Higher Education, Al-Maktaba Al-Asserya, 4-5.

Gohar, A. S., \& El-Basil, M. F. (2016). The Optimal Investment in Education, Al-Maktaba Al-Asserya, Mansoura, 77.

Gohar, A. S., \& El-Basil, M. F. (2018). The Pathway to Management Creativity in Educational Institutions of Arab Countries.

Gomaa, M. H. (2015). Education and Issues of The Age (p. 88). Cairo: Dar Al-Gawhara for Publishing \& Distribution.

Maher, A. (2007). Strategic Management is the Practical Guide for Mangers.

Mushier, E.-S. (2013). Percieving the Meaning of Education, Fragility and Conflict. Futures, 43, 10. (Emad Eddin Abdul-Raziq, Trans.).

Nawal, A. (2014). Nasser: Future of Educational Studies, The Egyptian Public Board for Books, Cairo, 104.

Tilac, J. Y. G. (2008). Higher Education: Is It Public Interest or Commodity for Trading? Commitment to Higher Education or Commitment to Trading. Futures, 38, 679. (Emad Eddin Abdul-Raziq, Trans.). 